\title{
Crystallization and Characterization of Magnesium Methanesulfonate Hydrate $\mathrm{Mg}\left(\mathrm{CH}_{3} \mathrm{SO}_{3}\right)_{2} \cdot 12 \mathrm{H}_{2} \mathrm{O}$
}

\author{
F. Elif Genceli Guner, ${ }^{*}{ }^{\dagger}$ Martin Lutz, ${ }^{\star}$ Toshimitsu Sakurai, ${ }^{\S}$ Anthony L. Spek, ${ }^{*}$ and \\ Takeo Hondoh ${ }^{\S}$ \\ ${ }^{\dagger}$ Laboratory for Process Equipment, Delft University of Technology, Leeghwaterstraat 44, \\ 2628 CA Delft, The Netherlands, "Crystal and Structural Chemistry, Bijvoet Center for \\ Biomolecular Research, Utrecht University, Padualaan 8, 3584 CH Utrecht, The Netherlands, and \\ ${ }^{\S}$ Institute of Low Temperature Science, Hokkaido University, N19W8 Sapporo, Japan
}

Received February 19, 2010; Revised Manuscript Received July 28, 2010

\begin{abstract}
Records of methanesulfonate acid in ice cores play an important role in reconstruction of the past history of marine productivity, sea ice extent, and major El Niño event activities related to climate changes. Considering the lack of thermodynamic and crystal structure data, crystallization conditions below zero degrees Celsius were mimicked in the laboratory, and magnesium methanesulfonic hydrate crystals, $\mathrm{Mg}\left(\mathrm{CH}_{3} \mathrm{SO}_{3}\right)_{2} \cdot 12 \mathrm{H}_{2} \mathrm{O}\left(\mathrm{i} . \mathrm{e}\right.$., $\left.\left[\mathrm{Mg}\left(\mathrm{H}_{2} \mathrm{O}\right)_{6}\right]\left(\mathrm{CH}_{3} \mathrm{SO}_{3}\right)_{2} \cdot 6 \mathrm{H}_{2} \mathrm{O}\right)$ were grown from solution by cooling crystallization and by eutectic freeze crystallization. The solubility lines between -5 and $+21{ }^{\circ} \mathrm{C}$ and between 0 and $25 \mathrm{wt} \%$ are presented. The eutectic point of the system is detected at $-5^{\circ} \mathrm{C}$ and $14 \mathrm{wt} \%$. The crystal structure analysis and the molecular arrangement of these crystals were determined using single crystal X-ray diffraction (XRD). Reflections were measured at a temperature of $110(2) \mathrm{K}$. The structure is trigonal with space group $R \overline{3}$ (no. 148). The crystal is a colorless block with the following parameters: $a=b=9.27150(8) \AA$, $c=21.1298(4) \AA, V=1572.99(4) \AA^{3}, Z=3$, and $D_{\text {calc }}=$ $1.364 \mathrm{~g} / \mathrm{cm}^{3}$. The Raman spectrum of $\mathrm{Mg}\left(\mathrm{CH}_{3} \mathrm{SO}_{3}\right)_{2} \cdot 12 \mathrm{H}_{2} \mathrm{O}$ salt has been recorded and the principal absorption modes identified. Thermogravimetric analysis confirmed the stochiometry of the $\mathrm{Mg}\left(\mathrm{CH}_{3} \mathrm{SO}_{3}\right)_{2} \cdot 12 \mathrm{H}_{2} \mathrm{O}$ salt.
\end{abstract}

\section{Introduction}

At subzero temperatures, information on the thermodynamics and molecular structures of several salts (acid/ organic compounds) formed from aqueous solutions and of gas-hydrates formed under pressure from aqueous solutions is largely lacking due to difficult and unfavorable working conditions, inadequate measurement techniques, and difficulty of handling and sample preparation of temperature sensitive compounds for single crystal X-ray data collection. Although many investigations have been carried out in the fields of physical, biological, and chemical science, our ignorance at low temperatures is still enormous.

Detection of new molecular structures synthesized from aqueous solutions at low temperature is possible during solubility data collection research (e.g., Meridianite). ${ }^{1-5}$ Discovering the natural occurrence of these structures in cold regions such as at the Poles contributes scientific knowledge as a "new mineral discovery" and provides records of past climate and atmospheric conditions and living organisms preserved in the ice cores.

In this respect, detection of methanesulfonic acid (MSA, $\left.\mathrm{CH}_{3} \mathrm{SO}_{3} \mathrm{H}\right)$ in the ice cores has become of primary importance, since it is a tool for reconstructing the past history of marine productivity, ${ }^{6,7}$ sea ice extent, ${ }^{8,9}$ and major El Niño events $^{10}$ related to climate changes. MSA is formed by the oxidation processes of dimethyl sulfide (DMS) in the atmosphere. DMS is produced by processes involving phytoplankton, and it is highly volatile and released to the atmosphere. ${ }^{11,12}$ In ice cores, MSA is deposited as methanesulfonate salts ${ }^{13}$ rather than in acid form, probably due to its fixation on alkaline

*Corresponding author. E-mail addresses: egenceli@hotmail.com, f.e.genceli@tudelft.nl. Telephone numbers: +31 (0) 6422086 14, +31 (0)15 2786605. Fax number: +31 (0)15 2782460 .

(C) 2010 American Chemical Society particles of marine or continental origin during the glacial period. ${ }^{14}$ MSA has been studied extensively for its important role in biological and environmental systems. ${ }^{15-29}$ There is broad literature of $\mathrm{Na}(\mathrm{I}), \mathrm{Ag}(\mathrm{I}), \mathrm{Mg}(\mathrm{II}), \mathrm{Ca}(\mathrm{II}), \mathrm{V}(\mathrm{III})$, $\mathrm{Cr}(\mathrm{III}), \mathrm{Mn}(\mathrm{II}), \mathrm{Fe}(\mathrm{II}), \mathrm{Co}(\mathrm{II}), \mathrm{Ni}(\mathrm{II}), \mathrm{Cu}(\mathrm{II}), \mathrm{Zn}(\mathrm{II}), \mathrm{Sr}(\mathrm{II})$, Cd(II), Ba(II), La(III), Ce(III), Nd(III), Sm(III), Gd(III), $\mathrm{Tb}(\mathrm{III}), \mathrm{Er}(\mathrm{III}), \mathrm{Yb}(\mathrm{III})$, and Lu(III) methanesulfonates for their synthesis, characterization, structure, and some of their thermal behavior at room and higher temperatures, ${ }^{30-44}$ since these materials are extremely important in catalytic chemistry and electrochemistry. At room and higher temperatures, these methanesulfonate salts tend to form tetra- and dihydrates, as well as existing in anhydrous crystals. However, still very little is known about methanesulfonate salts' low temperature structures, phase diagrams, and eutectic temperatures, e.g. magnesium methanesulfonate salt.

Previous studies show that $\mathrm{Na}^{+}$is the most abundant; $\mathrm{Mg}^{2+}$ and $\mathrm{CH}_{3} \mathrm{SO}_{3}{ }^{-}$are the minor ions in ice cores. ${ }^{45-47} \mathrm{This}$ suggests that crystallization of $\mathrm{NaCH}_{3} \mathrm{SO}_{3} \cdot n \mathrm{H}_{2} \mathrm{O}$ in ice cores is more probable than $\mathrm{Mg}\left(\mathrm{CH}_{3} \mathrm{SO}_{3}\right)_{2} \cdot n \mathrm{H}_{2} \mathrm{O}$ crystallization. However, besides ion concentration, environment and salt's eutectic temperatures play important roles in the type of the methanesulfonate salt formation. In this research, we focused on the missing knowledge on magnesium methanesulfonate. Considering the lack of crystal structure data, the crystallization conditions are mimicked at the laboratory below zero degrees Celsius, and magnesium methanesulfonate salt crystals were produced by eutectic freeze crystallization and by cooling crystallization. Produced crystals were analyzed by single-crystal X-ray diffraction (XRD). For the first time, the $\mathrm{Mg}\left(\mathrm{CH}_{3} \mathrm{SO}_{3}\right)_{2} \cdot 12 \mathrm{H}_{2} \mathrm{O}$ (i.e., $\left.\left[\mathrm{Mg}\left(\mathrm{H}_{2} \mathrm{O}\right)_{6}\right]\left(\mathrm{CH}_{3} \mathrm{SO}_{3}\right)_{2} \cdot 6 \mathrm{H}_{2} \mathrm{O}\right)$ crystal structure was described. The purpose of this work was to investigate the solubility line and eutectic point for the $\mathrm{Mg}\left(\mathrm{CH}_{3} \mathrm{SO}_{3}\right)_{2}-\mathrm{H}_{2} \mathrm{O}$ system and the properties of the 
$\mathrm{Mg}\left(\mathrm{CH}_{3} \mathrm{SO}_{3}\right)_{2} \cdot 12 \mathrm{H}_{2} \mathrm{O}$ salt such as crystallization habit, crystal structure, thermal behavior, and Raman spectra.

\section{Experimental Section}

Experimental Setup. Experiments were performed in a $2 \mathrm{~L}$, batch type, cylindrical jacketed glass vessel located in a climate room. The vessel was equipped with a three-leg scraper to prevent ice and salt scaling at the wall so as to provide mixing. Cooling was achieved by circulating ethylene glycol coolant from a Lauda RK $8 \mathrm{KP}$ bath through the cylinder jacket. In so doing, the temperature of the cooling liquid was controlled with an accuracy of $\pm 0.1-0.5{ }^{\circ} \mathrm{C}$. The temperature of the $\mathrm{Mg}\left(\mathrm{CH}_{3} \mathrm{SO}_{3}\right)_{2}$ solution was measured using an ASL F250 precision thermometer connected to a PT-100 temperature sensor with an accuracy of $\pm 0.01{ }^{\circ} \mathrm{C}$ and a resolution of $0.001{ }^{\circ} \mathrm{C}$. A more detailed description of the setup is given elsewhere. ${ }^{48}$ The temperature of the climate room was regulated simultaneously with the crystallizer set temperature.

Preparation of Solutions. Thirty weight percent $\mathrm{Mg}\left(\mathrm{CH}_{3} \mathrm{SO}_{3}\right)_{2}$ solutions, prepared with $99 \mathrm{wt} \%$ methanesulfonic acid magnesium salt (Daniel Fine Chemicals, CAS No. 62512-10-1) and ultrapure water of $18.2 \mathrm{~m} \Omega$, were used.

The cation and anion concentrations in the magnesium methanesulfonate solutions and in the crystals were measured off line using inductively coupled plasma atomic emission spectrometry (ICP-AES) and ion chromatograph with an error of $\pm 2.5 \%$.

Experimental Procedure. Experimental Setups. Unseeded batch crystallization experiments were started by stabilizing the solution at $30^{\circ} \mathrm{C}$ for $2 \mathrm{~h}$. The mixing rate was $80 \mathrm{rpm}$. A cooling rate of $4{ }^{\circ} \mathrm{C} / \mathrm{h}$ was applied until a temperature jump due to exothermic formation of the salt crystals was detected. When crystallization occurred, the coolant temperature was set constant to a desired value and the crystallizer was allowed to respond. When, after about $48-72 \mathrm{~h}$, no changes in temperature inside the crystallizer were noticed, the solution was expected to be sufficiently equilibrated in the presence of salt, ice, or ice and salt together, and the sample was taken from the solution. Salt samples were collected with a precooled syringe from the bottom outlets of the crystallizer. All salt samples were directly vacuum filtered using a jacket-cooled filter. The data from the temperature sensors were collected every $20 \mathrm{~s}$ and were recorded with Lab View. The solution samples were later analyzed using ICP-AES and ion chromatograph. These data were used to construct the phase diagram of the $\mathrm{Mg}\left(\mathrm{CH}_{3} \mathrm{SO}_{3}\right)_{2}-\mathrm{H}_{2} \mathrm{O}$ system (see below).

Picturing and Salt Preserving. Salt samples from each setup were observed under a Leica WILD M10 stereomicroscope equipped with a Nikon Coolpix 4500 camera.

The salt crystals collected were preserved well isolated at $-20{ }^{\circ} \mathrm{C}$ for the structure determination.

XRD Measurement. Reflections (14756) were measured on a Nonius Kappa CCD diffractometer with a rotating anode (graphite monochromator, $\lambda=0.71073 \AA$ ) up to a resolution of $(\sin \theta / \lambda)_{\max }=0.81 \AA^{-1}$ at a temperature of $110(2) \mathrm{K}$. Integration of the intensities was performed with the program Eval15. ${ }^{49}$ The program SADABS ${ }^{50}$ was used for absorption correction and scaling $(0.75-0.90$ correction range). 1551 reflections were unique $\left(R_{\text {int }}=0.021\right)$, of which 1481 were observed $[I>2 \sigma(I)]$. The structure was solved with Direct Methods using the program SHELXS- $97^{51}$ and refined with SHELXL-97 $7^{51}$ against $F^{2}$ of all reflections. Nonhydrogen atoms were refined with anisotropic displacement

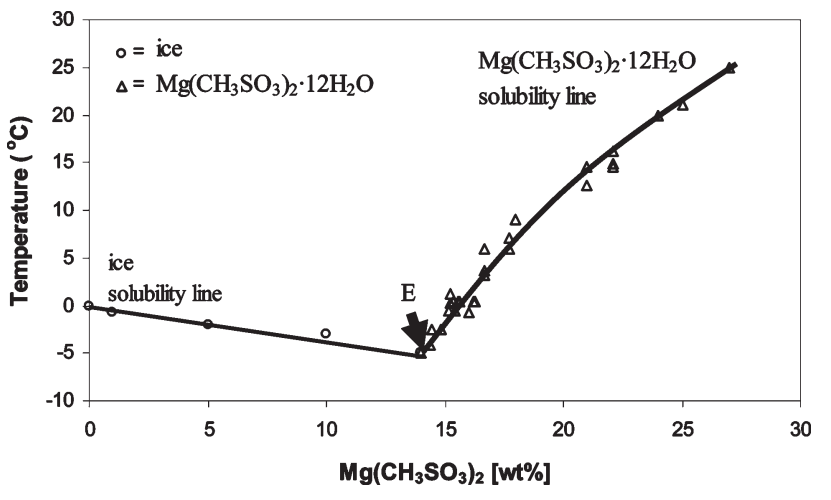

Figure 1. Phase diagram of the $\mathrm{Mg}\left(\mathrm{CH}_{3} \mathrm{SO}_{3}\right)_{2}-\mathrm{H}_{2} \mathrm{O}$ system. $E$ is the eutectic point.

parameters. Hydrogen atoms were located in difference Fourier maps and refined freely with isotropic displacement parameters. 57 parameters were refined with no restraints. R1/wR2 [I $>2 \sigma(I)]: 0.0187 / 0.0566$. R1/wR2 [all refl]: 0.0197/ 0.0574. $S=1.050$. Extinction parameter: 0.0029(5). Residual electron density between -0.35 and $0.37 \mathrm{e} / \AA^{3}{ }^{3}$. Geometry calculations and checking for higher symmetry was performed with the PLATON program. ${ }^{52}$

Thermogravimetric Analysis. The thermogravimetric analysis (TGA) of the crystal was done with a SDT 2960 (TA Instruments) with a temperature accuracy and precision of $\pm 1{ }^{\circ} \mathrm{C}$ and $\pm 0.5^{\circ} \mathrm{C}$, respectively, and a weight sensitivity of $0.1 \mu \mathrm{g}$ and a weight accuracy of $\pm 1 \%$. TGA was carried out in a helium atmosphere (with a purge rate of $100 \mathrm{~mL} / \mathrm{min}$ ) at a heating rate of $5^{\circ} \mathrm{C} / \mathrm{min}$ from 20 to $1100^{\circ} \mathrm{C}$.

Micro-Raman Spectroscopy. Raman spectroscopy was applied for characterization of the $\mathrm{Mg}\left(\mathrm{CH}_{3} \mathrm{SO}_{3}\right)_{2} \cdot 12 \mathrm{H}_{2} \mathrm{O}$ crystals. A Renishaw Ramanscope System 2000, equipped with a $20 \mathrm{~mW} \mathrm{Ar}{ }^{+}$laser $(\lambda=514 \mathrm{~nm})$ was used to record Raman spectra. A Leica DMLM PL Fluotar L50x/0.55 microscope was used to determine the analyzed surface of the sample. The spectral resolution was $\sim 1 \mathrm{~cm}^{-1}$ within the range $160-4000 \mathrm{~cm}^{-1}$. To investigate the sample at low temperature, $\mathrm{Mg}\left(\mathrm{CH}_{3} \mathrm{SO}_{3}\right)_{2} \cdot 12 \mathrm{H}_{2} \mathrm{O}$ crystals were kept inside an insulating vessel filled with frozen carbon dioxide prior to the measurements. A Linkam THM600 flow cell was used for the measurement below the freezing point. The cell was precooled with circulating ethylene glycol, which was set at $-10{ }^{\circ} \mathrm{C}$, and by placing frozen carbon dioxide (dry ice) inside the cell. After substantial precooling of the cell, the sample was placed inside and the spectra were recorded. Crystals in the range $160-4000 \mathrm{~cm}^{-1}$ were analyzed by continuous extended scanning, with a detection time of $20 \mathrm{~s}$.

\section{Results and Discussion}

The Crystals. Colorless salt samples, crystallized using pure magnesium methanesulfonate solutions, were collected from the crystallization setup. The samples were produced using eutectic freeze or cooling crystallization, working near the eutectic point. The phase diagram of the $\mathrm{Mg}\left(\mathrm{CH}_{3} \mathrm{SO}_{3}\right)_{2}-$ $\mathrm{H}_{2} \mathrm{O}$ system is presented in Figure 1. The eutectic point $(E)$ of ice $-\mathrm{Mg}\left(\mathrm{CH}_{3} \mathrm{SO}_{3}\right)_{2} \cdot 12 \mathrm{H}_{2} \mathrm{O}$ crystals is detected at $-5^{\circ} \mathrm{C}$ and $14 \mathrm{wt} \%$.

From the photograph in Figure 2, it can be seen that the crystals are well faceted.

All the salt samples directly filtered from the crystallizer were found to be $\mathrm{Mg}\left(\mathrm{CH}_{3} \mathrm{SO}_{3}\right)_{2} \cdot 12 \mathrm{H}_{2} \mathrm{O}$ crystals. 

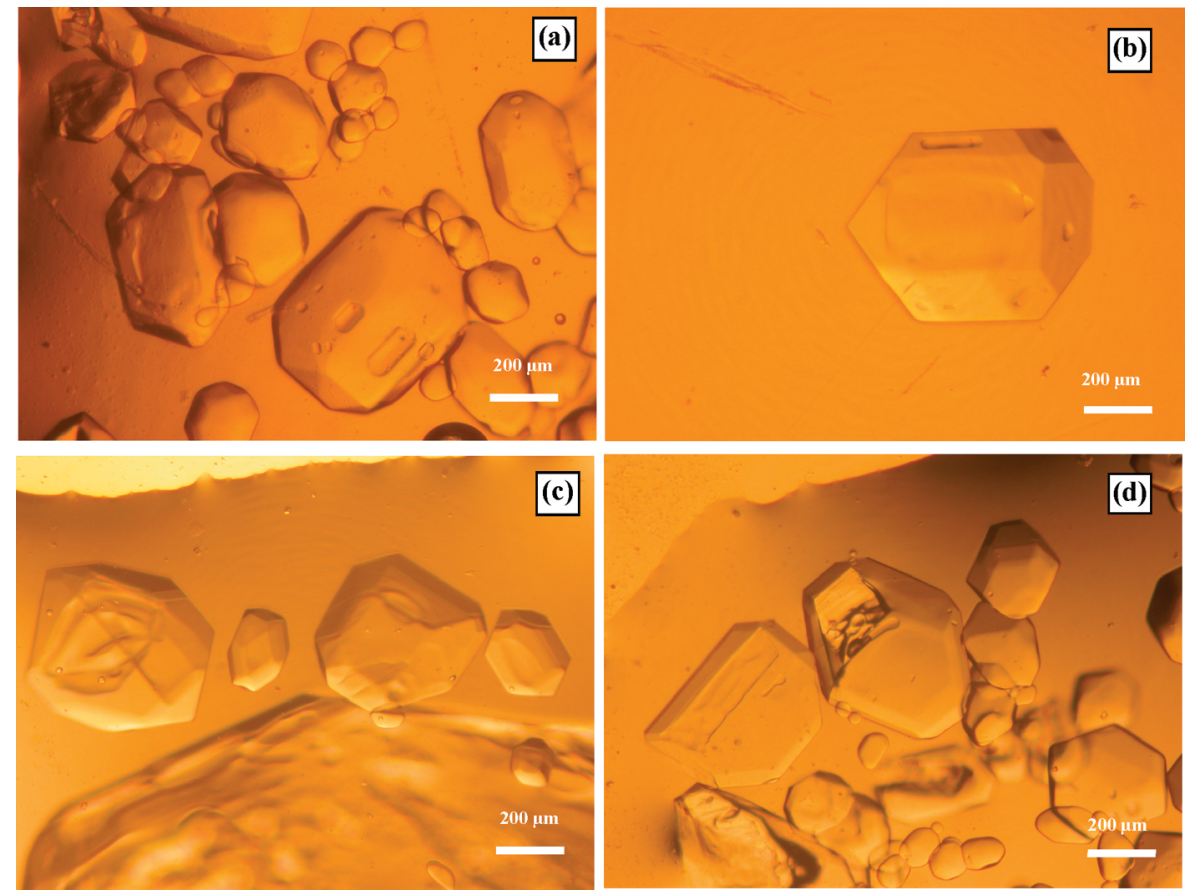

Figure 2. $(\mathrm{a}-\mathrm{d})$ Optical images of $\mathrm{Mg}\left(\mathrm{CH}_{3} \mathrm{SO}_{3}\right)_{2} \cdot 12 \mathrm{H}_{2} \mathrm{O}$ crystals.

Table 1. Summary Crystal Data and Data Collection

\begin{tabular}{ll}
\hline \multicolumn{1}{c}{ empirical formula } & \multicolumn{1}{c}{$\mathrm{C}_{2} \mathrm{H}_{30} \mathrm{MgO}_{18} \mathrm{~S}_{2}$} \\
\hline $\mathrm{FW}\left(\mathrm{g} \cdot \mathrm{mol}^{-1}\right)$ & 430.69 \\
$T(\mathrm{~K})$ & $110(2)$ \\
$\lambda(\AA)$ & 0.71073 \\
crystal system & trigonal \\
space group & $R \overline{3}$ (no. 148) \\
unit cell dimensions & \\
$a=b(\AA)$ & $9.27150(8)$ \\
$c(\AA)$ & $21.1298(4)$ \\
$\gamma(\mathrm{deg})$ & 120.00 \\
$V\left(\AA^{3}\right)$ & $1572.99(4)$ \\
$Z$ & 3 \\
$D_{\mathrm{m}}\left(\mathrm{g} / \mathrm{cm}^{3}\right)$ & 1.364 \\
$\left.\mu(\mathrm{mm})^{-1}\right)$ & 0.354 \\
$F(000)$ & 690 \\
crystal size (mm $\left.{ }^{3}\right)$ & $0.3 \times 0.3 \times 0.3$ \\
$\theta$ range $($ deg $)$ & $2.71 \rightarrow 35.00$ \\
reflections collected & 14756 \\
independent reflections & $1551\left(R_{\text {int }}=0.0209\right)$ \\
data/restraints/parameters & $1551 / 0 / 57$ \\
$I$ & 1.050 \\
$R[I>2 \sigma(I)]$ & $\mathrm{R} 1=0.0187$ \\
& wR2 $=0.0566$ \\
$R$ indices (all data) & $\mathrm{R} 1=0.0197$ \\
& wR2 $=0.0574$
\end{tabular}

XRD Measurements: Crystal Structure Determination. The crystal data and a summary of the data collection are given in Table 1.

The magnesium center is located on a crystallographic $\overline{3}$ center (Wyckoff position $a$ ) and surrounded by six symmetry related water molecules, forming an octahedral coordination geometry (Figure 3). Due to this symmetry, all $\mathrm{Mg}-\mathrm{O}$ distances are equal and the $\mathrm{O}-\mathrm{Mg}-\mathrm{O}$ angles are allowed to deviate from the perfect $90^{\circ}$ (trigonal distortion), resulting in an rms deviation from perfect $O_{h}$ symmetry of only $0.0157 \mathrm{~A}^{53}$ Selected bond distances and angles are given in Table 2. The angle between the least-squares plane of the water molecule and the $\mathrm{Mg}-\mathrm{O}$ vector is $11.9(12)^{\circ}$, indicating an essentially planar trigonal coordination mode of the water. ${ }^{54}$ The $\left[\mathrm{Mg}\left(\mathrm{H}_{2} \mathrm{O}\right)_{6}\right]^{2+}$ motif is very common in crystal structures, ${ }^{55}$
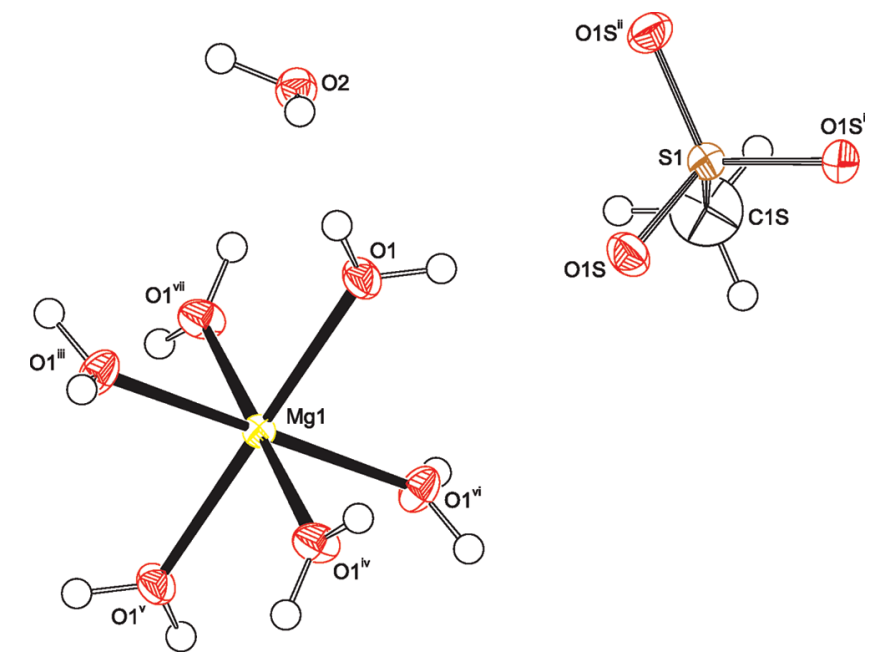

Figure 3. Displacement ellipsoid plot of $\mathrm{Mg}\left(\mathrm{CH}_{3} \mathrm{SO}_{3}\right)_{2} \cdot 12 \mathrm{H}_{2} \mathrm{O}$ in the crystal (50\% probability level). Symmetry operations: (i) $1-y$, $x-y, z$; (ii) $1-x+y, 1-x, z$; (iii) $-y, x-y, z$; (iv) $-x+y,-x, z$; (v) $-x,-y,-z$; (vi) $y,-x+y,-z$; (vii) $x-y, x,-z$.

Table 2. Selected Distances $(\stackrel{\AA}{\mathrm{A}})$ and Angles (deg) in the Crystal Structure of $\mathrm{Mg}\left(\mathrm{CH}_{3} \mathrm{SO}_{3}\right)_{2} \cdot 12 \mathrm{H}_{2} \mathrm{O}^{a}$

\begin{tabular}{lllr}
\hline $\mathrm{Mg} 1-\mathrm{O} 1$ & $2.0517(4)$ & $\mathrm{O} 1-\mathrm{Mg} 1-\mathrm{O} 1^{\mathrm{iii}}$ & $90.521(16)$ \\
$\mathrm{S} 1-\mathrm{O} 1 \mathrm{~S}$ & $1.4583(4)$ & $\mathrm{O} 1-\mathrm{Mg} 1-\mathrm{O}^{\mathrm{vi}}$ & $89.481(16)$ \\
$\mathrm{S} 1-\mathrm{C} 1 \mathrm{~S}$ & $1.7571(12)$ & $\mathrm{O} 1 \mathrm{~S}-\mathrm{S} 1-\mathrm{O} 1 \mathrm{~S}^{\mathrm{i}}$ & $112.059(17)$ \\
& & $\mathrm{O} 1 \mathrm{~S}-\mathrm{S} 1-\mathrm{C} 1 \mathrm{~S}$ & $106.742(19)$
\end{tabular}

\footnotetext{
${ }^{a}$ Symmetry operations: (i) $1-y, x-y, z$; (iii) $-y, x-y, z$; (vi) $y,-x+$ $y,-z$.
}

and even in biological systems, the first coordination shell of magnesium often consists of six water molecules. ${ }^{56,57}$ The Cambridge Structural Database ${ }^{58}$ contains 160 entries with the $\left[\mathrm{Mg}\left(\mathrm{H}_{2} \mathrm{O}\right)_{6}\right]^{2+}$ motif (update February 2009), but this motif is also found in purely inorganic crystal structures such as in our recently published magnesium sulfate undecahydrate 
$\left(\left[\mathrm{Mg}\left(\mathrm{H}_{2} \mathrm{O}\right)_{6}\right]\left(\mathrm{SO}_{4}\right) \cdot 5 \mathrm{H}_{2} \mathrm{O}\right.$ or the more common formulation $\left.\mathrm{Mg}\left(\mathrm{SO}_{4}\right) \cdot 11 \mathrm{H}_{2} \mathrm{O}\right){ }^{1}$

The methanesulfonate ion is not directly coordinated to the magnesium but is the acceptor of hydrogen bonds from the coordinated water molecules. The sulfur and carbon atoms are located on a crystallographic 3-fold axis (Wyckoff position $c$ ). Because the multiplicity of this site is twice the multiplicity of the magnesium site, the stoichiometry is $2: 1$. The methyl group fulfills the 3 -fold symmetry and is not disordered.

In the crystal structure there is an additional uncoordinated water molecule. This molecule is located on a general position (Wyckoff position $f$ ). Because the multiplicity of this site is six times the multiplicity of the magnesium site, the ratio is $6: 1$.

Crystal Packing of $\mathrm{Mg}\left(\mathrm{CH}_{3} \mathrm{SO}_{3}\right)_{2} \cdot \mathbf{1 2}_{2} \mathrm{O}$. The individual residues in the crystal structure of $\mathrm{Mg}\left(\mathrm{CH}_{3} \mathrm{SO}_{3}\right)_{2} \cdot 12 \mathrm{H}_{2} \mathrm{O}$ are linked by hydrogen bonds. The geometries of these bonds are given in Table 3. Hydrogen atom $\mathrm{H} 1 \mathrm{O}$ of the coordinated water is donating an intermolecular hydrogen bond with $\mathrm{O} 1 \mathrm{~S}$ of the $\mathrm{CH}_{3} \mathrm{SO}_{3}$ as acceptor. By symmetry, this results in an infinite two-dimensional layer in the crystallographic $a, b$ plane (Figure 4). These layers are connected by hydrogen bonds involving the uncoordinated water molecules. Every oxygen atom of the $\mathrm{CH}_{3} \mathrm{SO}_{3}$ thus accepts two hydrogen bonds. The uncoordinated water is acceptor and donor of two hydrogen bonds, respectively. The coordinated water is donor of two hydrogen bonds and is not an acceptor. The methyl group is not involved in weak $\mathrm{C}-\mathrm{H}$ hydrogen bonds. The shortest intermolecular H . . O distance is 2.982(13) $\AA$, which is much too long for a bonding interaction.

Table 3. Hydrogen Bonding Geometry ${ }^{a}$ in the Crystal Structure of $\mathrm{Mg}\left(\mathrm{CH}_{3} \mathrm{SO}_{3}\right)_{2} \cdot 12 \mathrm{H}_{2} \mathrm{O}^{b}$

\begin{tabular}{llllc}
\hline \multicolumn{1}{c}{$\mathrm{D}-\mathrm{H} \cdots \mathrm{A}$} & $\mathrm{D}-\mathrm{H}(\AA)$ & $\mathrm{H} \cdots \mathrm{A}(\AA)$ & $\mathrm{D} \cdots \mathrm{A}(\AA)$ & $\mathrm{D}-\mathrm{H} \cdots \mathrm{A}(\mathrm{deg})$ \\
\hline $\mathrm{O} 1-\mathrm{H} 1 \mathrm{O} \cdots \mathrm{O} 1 \mathrm{~S}$ & $0.831(12)$ & $1.946(12)$ & $2.7726(6)$ & $172.9(11)$ \\
$\mathrm{O} 1-\mathrm{H} 2 \mathrm{O} \cdots \mathrm{O} 2$ & $0.841(12)$ & $1.943(12)$ & $2.7791(6)$ & $172.7(12)$ \\
$\mathrm{O} 2-\mathrm{H} 3 \mathrm{O} \cdots \mathrm{O} 1 \mathrm{~S}^{\mathrm{i}}$ & $0.837(11)$ & $1.929(11)$ & $2.7583(6)$ & $171.0(11)$ \\
$\mathrm{O} 2-\mathrm{H} 4 \mathrm{O} \cdots \mathrm{O} 2^{\mathrm{ii}}$ & $0.848(12)$ & $1.899(12)$ & $2.7457(4)$ & $176.8(11)$
\end{tabular}

${ }^{a} \mathrm{X}$-ray distances, not normalized to tabulated neutron values. ${ }^{b}$ Symmetry operations: (i) ${ }^{2} / 3-x, 1 / 3-y, 1 / 3-z$; (ii) $y-1 / 3,1 / 3-$ $x+y,{ }^{1} / 3-z$.
The packing of the molecules in the unit cell, the orientation of the coordination polyhedra, and the location of the uncoordinated water molecules are shown in Figure 5.

Thermal Analysis. The thermal decomposition of magnesium methanesulfonate is illustrated in Figure 6. The result indicates that the structure contains twelve water molecules $\left(\mathrm{Mg}\left(\mathrm{CH}_{3} \mathrm{SO}_{3}\right)_{2} \cdot 12 \mathrm{H}_{2} \mathrm{O}\right)$ and exhibits four step decomposition. The first three steps involve dehydration of twelve water molecules. The last step is the decomposition of anhydrous $\mathrm{Mg}\left(\mathrm{CH}_{3} \mathrm{SO}_{3}\right)_{2}$.

The continuous weight loss until $75^{\circ} \mathrm{C}$ corresponds to the dehydration of $2 \mathrm{H}_{2} \mathrm{O}$ and formation of $\mathrm{Mg}\left(\mathrm{CH}_{3} \mathrm{SO}_{3}\right)_{2}$. $10 \mathrm{H}_{2} \mathrm{O}$. Magnesium methanesulfonate decahydrate is stable within the plateau region of $75-115^{\circ} \mathrm{C}$. The wide weight loss between 115 and $135^{\circ} \mathrm{C}$, as the second step, matches with loss of the further $8 \mathrm{H}_{2} \mathrm{O}$ and formation of a $\mathrm{Mg}\left(\mathrm{CH}_{3} \mathrm{SO}_{3}\right)_{2}$. $2 \mathrm{H}_{2} \mathrm{O}$ molecule. Magnesium methanesulfonate dehydrate is stable in the plateau from 135 to $190{ }^{\circ} \mathrm{C}$. The third step between 190 and $220^{\circ} \mathrm{C}$ corresponds to the loss of all the water in the structure and formation of anhydrous $\mathrm{Mg}\left(\mathrm{CH}_{3} \mathrm{SO}_{3}\right)_{2}$. The anhydrous salt, stable up to $450^{\circ} \mathrm{C}$, undergoes an abrupt change in mass loss until $540^{\circ} \mathrm{C}$ and ends up with a residue of

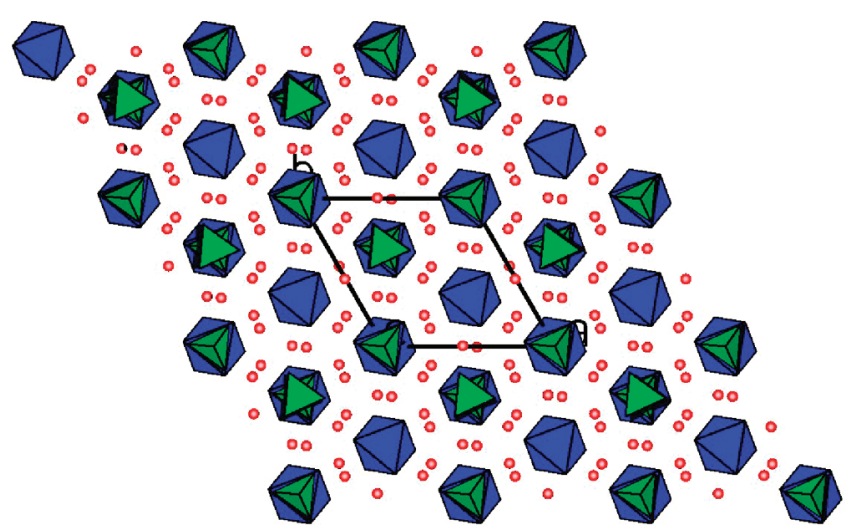

Figure 5. Packing of $\mathrm{Mg}\left(\mathrm{CH}_{3} \mathrm{SO}_{3}\right)_{2} \cdot 12 \mathrm{H}_{2} \mathrm{O}$ in the crystal. View along the crystallographic $c$-axis. Hydrogen atoms are omitted for clarity. The $\left[\mathrm{Mg}\left(\mathrm{H}_{2} \mathrm{O}\right)_{6}\right]$ octahedra are drawn in blue, the $\mathrm{CH}_{3} \mathrm{SO}_{3}$ tetrahedra are drawn in green, and the uncoordinated waters are red spheres of arbitrary radii.

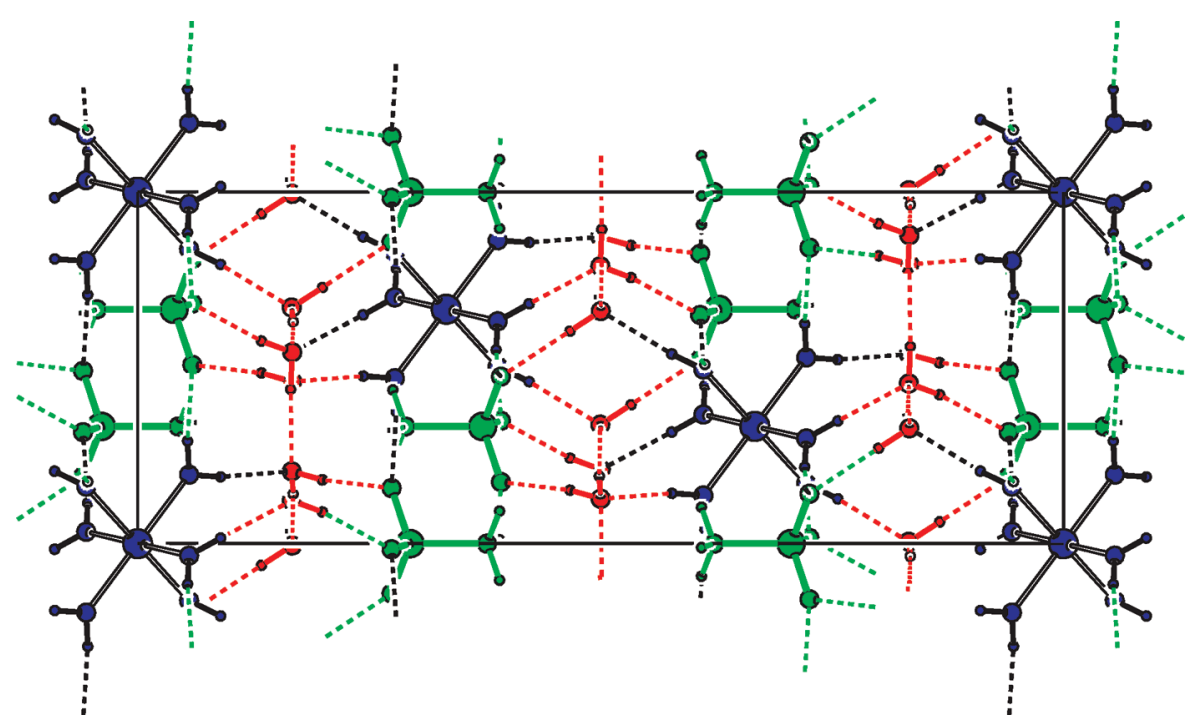

Figure 4. Hydrogen bonding in the crystal structure of $\mathrm{Mg}\left(\mathrm{CH}_{3} \mathrm{SO}_{3}\right)_{2} \cdot 12 \mathrm{H}_{2} \mathrm{O}$. View along the crystallographic $a$-axis. The $\left[\mathrm{Mg}\left(\mathrm{H}_{2} \mathrm{O}\right)_{6}\right]$ residues are drawn in blue, the $\mathrm{CH}_{3} \mathrm{SO}_{3}$ in green, and the uncoordinated water in red. 


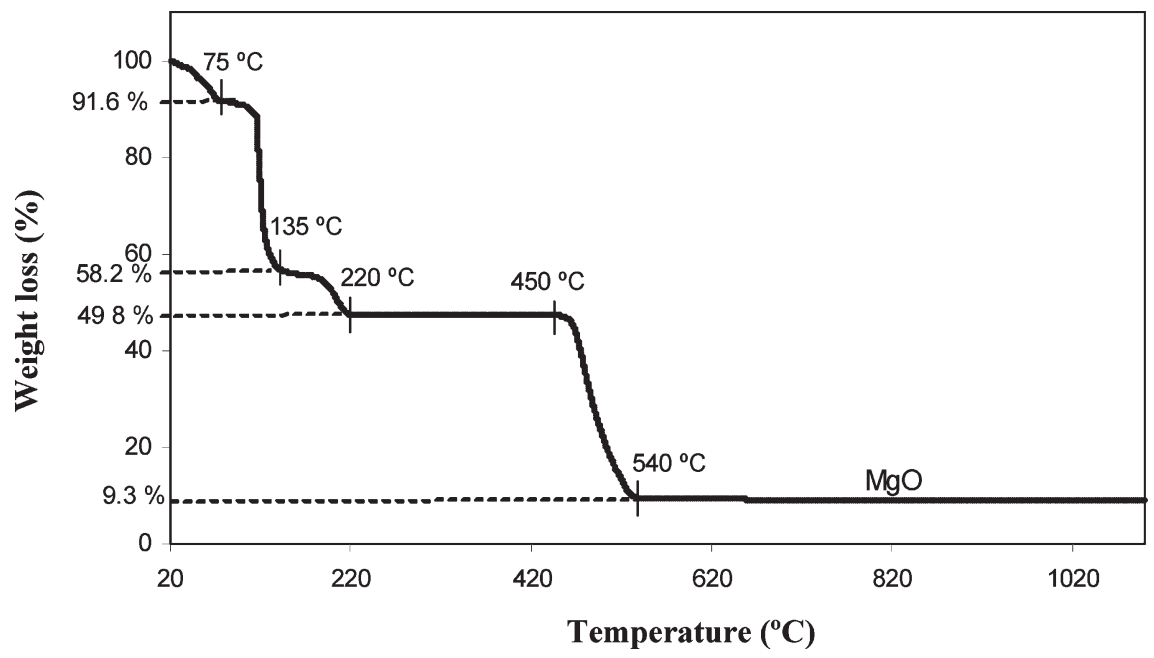

Figure 6. TGA curve of $\mathrm{Mg}\left(\mathrm{CH}_{3} \mathrm{SO}_{3}\right)_{2} \cdot 12 \mathrm{H}_{2} \mathrm{O}$.

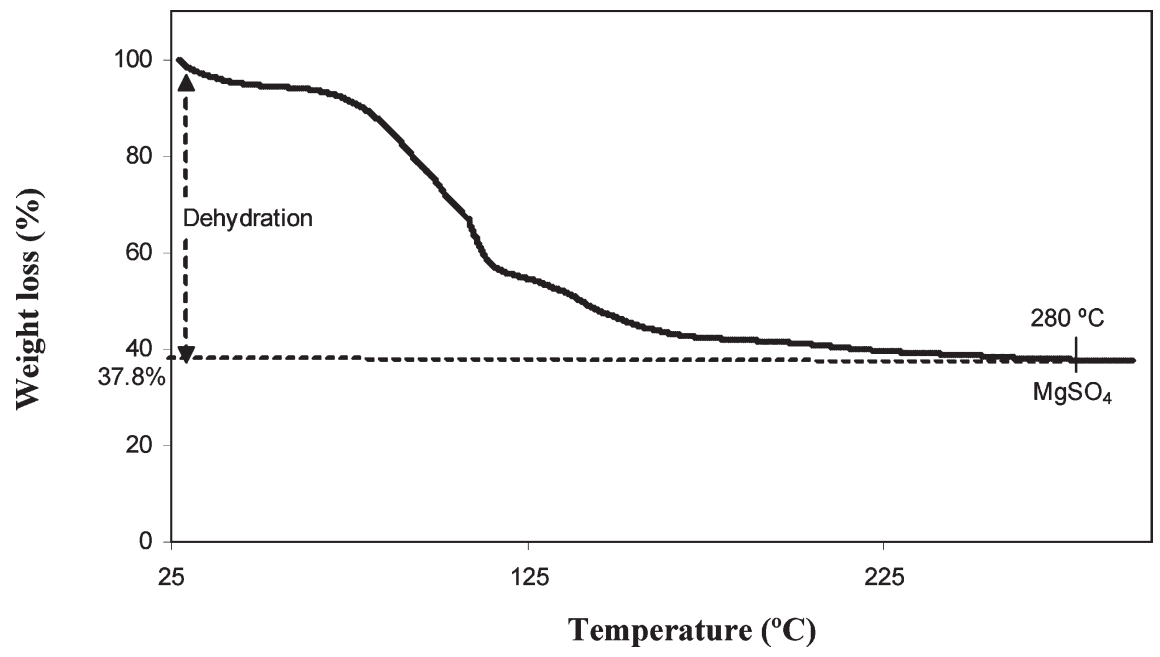

Figure 7. TGA curve of $\mathrm{MgSO}_{4} \cdot 11 \mathrm{H}_{2} \mathrm{O}^{1}$.

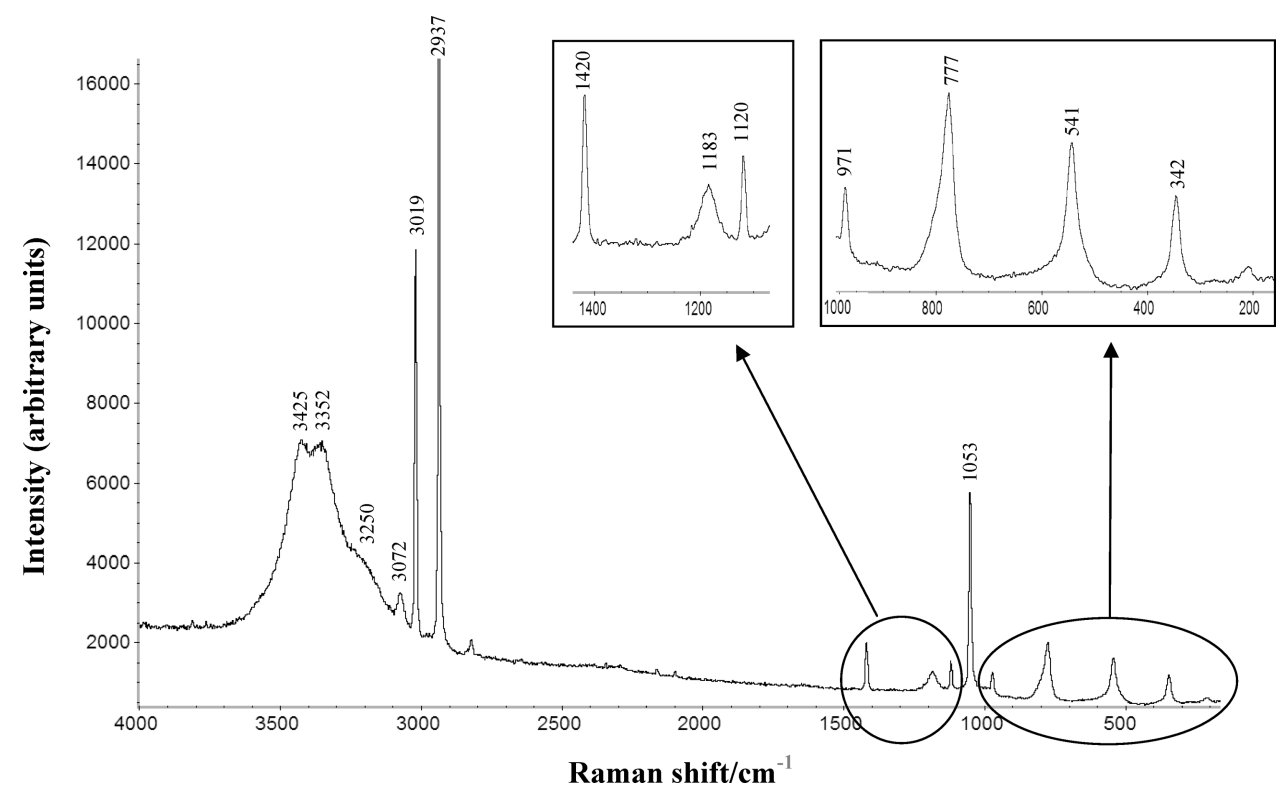

Figure 8. Raman spectra of the $\mathrm{Mg}\left(\mathrm{CH}_{3} \mathrm{SO}_{3}\right)_{2} \cdot 12 \mathrm{H}_{2} \mathrm{O}$ crystal.

$\mathrm{MgO}$ with the content of $9.3 \%$ (calculated value $=9.4 \%$ ). In the recent work of Wang et al., ${ }^{43}$ thermal decomposition of magnesium methanesulfonate dehydrate $\left(\mathrm{Mg}\left(\mathrm{CH}_{3} \mathrm{SO}_{3}\right)_{2}\right.$. $2 \mathrm{H}_{2} \mathrm{O}$ ) at $250-850{ }^{\circ} \mathrm{C}$ was studied. In their study, the final 
residue of magnesium methanesulfonate was detected as a mixture of $\mathrm{MgSO}_{4}$ and $\mathrm{MgO}$, since they used dynamic air instead of dynamic helium atmosphere, as in our case.

In Figure 7 , dehydration of $\mathrm{MgSO}_{4} \cdot 11 \mathrm{H}_{2} \mathrm{O}$ in helium atmosphere is presented. ${ }^{1}$ Unlike the $\mathrm{Mg}\left(\mathrm{CH}_{3} \mathrm{SO}_{3}\right)_{2} \cdot 12 \mathrm{H}_{2} \mathrm{O}$ thermal decomposition, in the TGA trace of $\mathrm{MgSO}_{4} \cdot 11 \mathrm{H}_{2} \mathrm{O}$, there is one single broad continuous weight loss until $280{ }^{\circ} \mathrm{C}$ which belongs to the dehydration step of eleven water molecules.

Micro-Raman Spectroscopy. The micro-Raman spectrum of a $\mathrm{Mg}\left(\mathrm{CH}_{3} \mathrm{SO}_{3}\right)_{2} \cdot 12 \mathrm{H}_{2} \mathrm{O}$ crystal, examined in the frequency region $160-4000 \mathrm{~cm}^{-1}$, is presented in Figure 8. In our study, the band assignments were made by comparing the results of the earlier work of Barletta et al., ${ }^{29}$ Socrates $^{59}$, and Thompson. ${ }^{60}$

The most significant peaks of the $\mathrm{Mg}\left(\mathrm{CH}_{3} \mathrm{SO}_{3}\right)_{2} \cdot 12 \mathrm{H}_{2} \mathrm{O}$ Raman spectra are the $v_{1}(\mathrm{C}-\mathrm{H})$ symmetric stretching band at $2937 \mathrm{~cm}^{-1}$ and the $v_{6}(\mathrm{C}-\mathrm{H})$ symmetric stretching band at $3019 \mathrm{~cm}^{-1}$. Magnesium methanesulfonate salt has an additional $v_{7}$ vibration $\left(\mathrm{CH}_{3}\right.$ deformation) at $1420 \mathrm{~cm}^{-1}$ and $v_{5}$ ( $\mathrm{SO}_{3}$ deformation) at $541 \mathrm{~cm}^{-1}$. Similar to the case of sodium methanesulfonate and cesium methanesulfonate salts, ${ }^{60}$ the Raman spectra show no band in the methyl group deformation spectral region $\left(1300-1400 \mathrm{~cm}^{-1}\right)$, presumably due to its weakness to record. The weak bonds recorded at $1183 \mathrm{~cm}^{-1}$ and $1120 \mathrm{~cm}^{-1}$ correspond to the $\mathrm{SO}_{3}$ stretch mode. The bands at $1053 \mathrm{~cm}^{-1}$ and $777 \mathrm{~cm}^{-1}$ are close to the frequency values observed in the literature and have been assigned to the $v_{4}(\mathrm{~S}-\mathrm{O})$ symmetric stretching band and the $v_{3}(\mathrm{C}-\mathrm{S})$ stretch mode, respectively. In the Raman spectra, magnesium methanesulfonate salt has the methyl rocking mode $\left(\mathrm{CH}_{3}\right.$ rock $)$ at $971 \mathrm{~cm}^{-1}$ and the sulfonate rocking $\left(\mathrm{SO}_{3}\right.$ rock) mode occurring at $342 \mathrm{~cm}^{-1}$.

The stretching modes of water incorporated in the lattice are located in the $3100-3650 \mathrm{~cm}^{-1}$ region. For $\mathrm{Mg}\left(\mathrm{CH}_{3} \mathrm{SO}_{3}\right)_{2}$. $12 \mathrm{H}_{2} \mathrm{O}$, there are two dominant bands resolved at $3425 \mathrm{~cm}^{-1}$ and $3352 \mathrm{~cm}^{-1}$ with potential shoulders at $3250 \mathrm{~cm}^{-1}$.

Assigning the peaks will be essential for applying the results to identify the inclusions in the Antarctic Ice, as demonstrated for $\mathrm{MgSO}_{4} \cdot 11 \mathrm{H}_{2} \mathrm{O}{ }^{2}$

\section{Conclusion}

$\mathrm{Mg}\left(\mathrm{CH}_{3} \mathrm{SO}_{3}\right)_{2} \cdot 12 \mathrm{H}_{2} \mathrm{O}$ was grown from magnesium methanesulfonate solution by eutectic freezing and by cooling crystallization. The crystal structure was determined at 110(2) K showing $\mathrm{Mg}\left(\mathrm{OH}_{2}\right)_{6}$ octahedra with $\overline{3}$ site symmetry and $\mathrm{CH}_{3} \mathrm{SO}_{3}$ anions on crystallographic 3 -fold rotation axes. Additionally, the crystal structure contains uncoordinated water molecules on general positions, resulting in an overall stochiometry of $\mathrm{Mg}\left(\mathrm{CH}_{3} \mathrm{SO}_{3}\right)_{2} \cdot 12 \mathrm{H}_{2} \mathrm{O}$. Thermogravimetric analysis proved the stoichiometry of the $\mathrm{Mg}\left(\mathrm{CH}_{3} \mathrm{SO}_{3}\right)_{2}$. $12 \mathrm{H}_{2} \mathrm{O}$ salt. The phase diagram of the $\mathrm{Mg}\left(\mathrm{CH}_{3} \mathrm{SO}_{3}\right)_{2}-\mathrm{H}_{2} \mathrm{O}$ system for the range $0-25 \mathrm{wt} \% \mathrm{Mg}\left(\mathrm{CH}_{3} \mathrm{SO}_{3}\right)_{2}$ and temperature -5 to $+21{ }^{\circ} \mathrm{C}$ is given. The eutectic point of the ice$\mathrm{Mg}\left(\mathrm{CH}_{3} \mathrm{SO}_{3}\right)_{2} \cdot 12 \mathrm{H}_{2} \mathrm{O}$ salt system was detected at $-5^{\circ} \mathrm{C}$ and 14 wt \%. The Raman spectrum has also been presented, and the principal faces exhibited by the crystal have been defined.

These investigations will contribute to scientific knowledge by helping to identify the magnesium methanesulfonate salts preserved in ice cores better. In particular with the Arctic research, the discovery and the preparation of new crystal structures in the laboratory under extreme conditions (at subzero temperatures) of unknown salts that reveal past climate, atmosphere, and living organisms' records becomes of utmost importance.

Acknowledgment. We would like to thank Avantium for the morphology prediction, Dr. Maria Dolores Hernandez Alonso and Dr. Guido Mul for Raman spectroscopy, Jacopo Giuntoli for TGA measurements, Michiel van Brink for ICPAES analysis, and Prof. dr. Gerda van Rosmalen, Prof. dr. Peter Cains, and Dr. Hugo Meekes for their scientific input.

Supporting Information Available: Crystallographic files in CIF format and difference Fourier map in the methyl plane (H-atoms omitted in the calculation). This material is available free of charge via the Internet at http://pubs.acs.org.

\section{References}

(1) Genceli, F. E.; Lutz, M.; Spek, A. L.; Witkamp, G.-J. Cryst. Growth Des. 2007, 7, 2460-2466.

(2) Genceli, F. E.; Horikawa, S.; Iizuka, Y.; Sakurai, T.; Hondoh, T.; Kawamura, T.; Witkamp, G. W. J. Glaciol. 2009, 55, 117-122.

(3) Peterson, R. C.; Wang, R. Geology 2006, 34, 957-960.

(4) Peterson, R. C.; Nelson, W.; Madu, B.; Shurvell, H. F. Am. Mineral. 2007, 92, 1756-1759.

(5) Fortes, A. D.; Wood, I. G.; Knight, K. S. Phys. Chem. Miner. 2008, $35,207-221$.

(6) Legrand, M.; Feniet-Saigne, C.; Saltzman, E. S.; Germain, C.; Barkov, N. I.; Petrov, V. N. Nature 1991A, 350, 144-146.

(7) Legrand, M.; Feniet-Saigne, C.; Saltzman, E. S.; Germain, C. J. Atmos. Chem. 1992, 14, 245-260.

(8) Curran, M. A. J.; van Ommen, T. D.; Morgan, V. I.; Phillips, K. L.; Palmer, A. S. Science 2003, 302, 1203-1206.

(9) Preunkert, S.; Jourdain, B.; Legrand, M.; Udisti, R.; Becagli, S.; Cerri, O. J. Geophys. Res. 2008, 113, D15302.

(10) Legrand, M.; Feniet-Saigne, C. Geophys. Res. Lett. 1991B, 21, 187-190.

(11) Cosme, E.; Hourdin, F.; Genthon, C.; Martinerie, P. J. Geophys. Res. 2005, 110, D03302.

(12) Fundel, F.; Fischer, H.; Weller, R.; Traufetter, F.; Oerter, H.; Miller, H. J. Geophys. Res. 2006, 111, D04103.

(13) Ohno, H.; Igarashi, M.; Hondoh, T. Earth Planet. Sci. Lett. 2005, 232, 171-178.

(14) Delmas, R. J.; Wagnon, P.; Goto-Azuma, K.; Kamiyama, K.; Watanabe, O. Tellus 2003, 55B, 71-79.

(15) Mihalopoulos, N.; Kerminen, V. M.; Kanakidou, M.; Berresheim, H.; Sciare, J. Atmos. Environ. 2007, 41, 6860-6871.

(16) Galloway, J. N.; Savoie, D. L.; Keene, W. C.; Prospero, J. M. Atmos. Environ. 1993, 27 A (2), 235-250.

(17) Bürgermeister, S.; Georgii, H.-W. Atmos. Environ. 1991, 25 A (3/4), $587-595$.

(18) Kerminen, V.-M.; Hillamo, R. E.; Wexler, A. S. J. Aerosol Sci. 1998, 29 (1), S247-S248.

(19) Kouvarakis, G.; Mihalopoulos, N. Atmos. Environ. 2002, 36, 929938.

(20) Moosvi, S. A.; McDonald, I. R.; Pearce, D. A.; Kelly, D. P.; Wood, A. P. Syst. Appl. Microbiol. 2005, 28, 541-554.

(21) Prospero, J. M.; Savoie, D. L.; Arimoto, R.; Olafsson, H.; Hjartarson, H. Sci. Total Environ. 1995, 160/161, 181-191.

(22) Li, S.-M.; Winchester, J. W. Atmos. Environ. 1989, 23 (11), 23872399.

(23) Li, S.-M.; Winchester, J. W. Atmos. Environ. 1989, 23 (11), 24012415.

(24) Peng, C.; Chan, C. K. Atmos. Environ. 2001, 35, 1183-1192.

(25) Hynes, A. J.; Wine, P. H.; Semmes, D. H. J. Phys. Chem. 1986, 90, $4148-4156$

(26) Saigne, C.; Legrand, M. Nature 1987, 330, 240-242.

(27) Saltelli, A.; Hjorth., J. J. Atmos. Chem. 1995, 21, 187-221.

(28) During, J. R.; Zhou, L.; Schwartz, T.; Gounev, T. J. Raman Spectrosc. 2000, 31, 193-202.

(29) Barletta, R. E.; Gros, B. N.; Herring, M. P. J. Raman Spectrosc. 2008, 40, 972-981.

(30) Paul, R. C.; Kapila, V. P.; Palta, N.; Sharma, S. K. Indian J. Chem. 1974, 12, 825.

(31) Charbonnier, F.; Faure, R.; Loiseleur, H. J. Appl. Crystallogr. 1975, 8, 400-401.

(32) Charbonnier, F.; Faure, R. J. Appl. Crystallogr. 1975, 8, 493-494. 
(33) Charbonnier, F.; Faure, R.; Loiseleur, H. J. Appl. Crystallogr. 1975, 8, 694-695.

(34) Charbonnier, F. Thermochim. Acta 1979, 33, 31-39.

(35) Garaud, Y.; Charbonnier, F.; Faure, R. J. Appl. Crystallogr. 1980, $13,190$.

(36) Wei, C. H.; Hingerty, B. E. Acta Crystallogr. 1981, B37, 1992-1997.

(37) Ramirez, A.; Gomez, M. L.; Guerrero, A. Thermochim. Acta 1988, $124,9-16$.

(38) Arico', E. M.; Zinner, L. B.; Apostolidis, C.; Dornberger, E.; Kanellakopulos, B.; Rebizant, J. J. Alloys Compd. 1997, 249, 111-115.

(39) Arico', E. M.; Zinner, L. B.; Kanellakopulos, B.; Dornberger, E.; Rebizant, J.; Apostolidis, C. J. Alloys Compd. 2001, 323-324, 39-44.

(40) De, F. V.; de Moura, M.; Do, R.; Matos, J.; De Farias, R. F. Thermochim. Acta 2004, 414, 159-166.

(41) Su, T. T.; Jiang, H.; Gong, H. Thermochim. Acta 2005, 435, 1-5.

(42) Wang, M.; Jiang, H.; Wang, Z. C. J. Therm. Anal. Calorim. 2006, 85 (3), 751-754.

(43) Wang, M.; Song, Z. G.; Jiang, H.; Gong, H. J. Therm. Anal. Calorim. 2009, 98, 801-806.

(44) Liu, Y.; Laskin, A. J. Phys. Chem. A 2009, 113, 1531-1538.

(45) Watanabe, O.; Jouzel, J.; Johnsen, S.; Parrenin, F.; Shoji, H.; Yoshida, N. Nature 2003, 422, 509-512.

(46) Bertler, N.; Mayewski, P. A.; Aristarain, A.; Barrett, P.; Becagli, S.; Bernardo, R.; Bo, S.; Xiao, C.; Curran, M.; Qin, D.; Dixon, D.; Ferron, F.; Fischer, H.; Frey, M.; Frezzotti, M.; Fundel, F.; Genthon, C.; Gragnani, R.; Hamilton, G.; Handley, M.; Hong, S.; Isaksson, E.; Kang, J.; Ren, J.; Kamiyama, K.; Kanamori, S.; Kärkäs, E.; Karlöf, L.; Kaspari, S.; Kreutz, K.; Kurbatov, A.;
Meyerson, E.; Ming, Y.; Zhang, M.; Motoyama, H.; Mulvaney, R.; Oerter, H.; Osterberg, E.; Proposito, M.; Pyne, A.; Ruth, U.; Simões, J.; Smith, B.; Sneed, S.; Teinilä, K.; Traufetter, F.; Udisti, R.; Virkkula, A.; Watanabe, O.; Williamson, B.; Winther, J.-G.; Li, Y.; Wolff, E.; Li, Z.; Zielinski, A. Ann. Glaciol. 2005, 41, 167-179.

(47) Iizuka, Y.; Horikawa, S.; Sakurai, T.; Johnson, S.; Dahl-Jensen, D.; Steffensen, J. P.; Hondoh, T. J. Geophys. Res. 2008, 113, D07303.

(48) Genceli, F. E.; Himawan, C.; Witkamp, G. J. J. Cryst. Growth 2005, 275 (1-2), e1757-e1762.

(49) Xian, X.; Schreurs, A. M. M.; Kroon-Batenburg, L. M. J. Acta Crystallogr. 2006, A62, s92.

(50) Sheldrick, G. M. SADABS: Area-Detector Absorption Correction, v2.10; Universität Göttingen: Germany, 1999.

(51) Sheldrick, G. M. Acta Crystallogr. 2008, A64, 112-122.

(52) Spek, A. L. J. Appl. Crystallogr. 2003, 36, 7-13.

(53) Pilati, T.; Forni, A. J. Appl. Crystallogr. 1998, 31, 503-504.

(54) McIntyre, G. J.; Ptasiewicz-Bak, H.; Olovsson, I. Acta Crystallogr. 1990, B46, 27-39.

(55) Bock, C. W.; Kaufman, A.; Glusker, J. P. Inorg. Chem. 1994, 33, 419-427.

(56) Kiriukhin, M. Y.; Collins, K. D. Biophys. Chem. 2002, 99, 155-168.

(57) Bock, C. W.; Markham, G. D.; Katz, A. K.; Glusker, J. P. Theor. Chem. Acc. 2006, 115, 100-112.

(58) Allen, F. H. Acta Crystallogr. 2002, B58, 380-388.

(59) Socrates, G. Infrared and Raman Characteristic Group Frequencies: Tables And Charts, 3rd ed.; John Wiley \& Sons Ltd.: Chichester, 2001; Table 22.1.

(60) Thompson, W. K. Spectrochim. Acta 1972, 28A, 1479-1484. 